\section{OAK RIDGE NATIONAL LABORATORY \\ MARTIN MARIETTA}

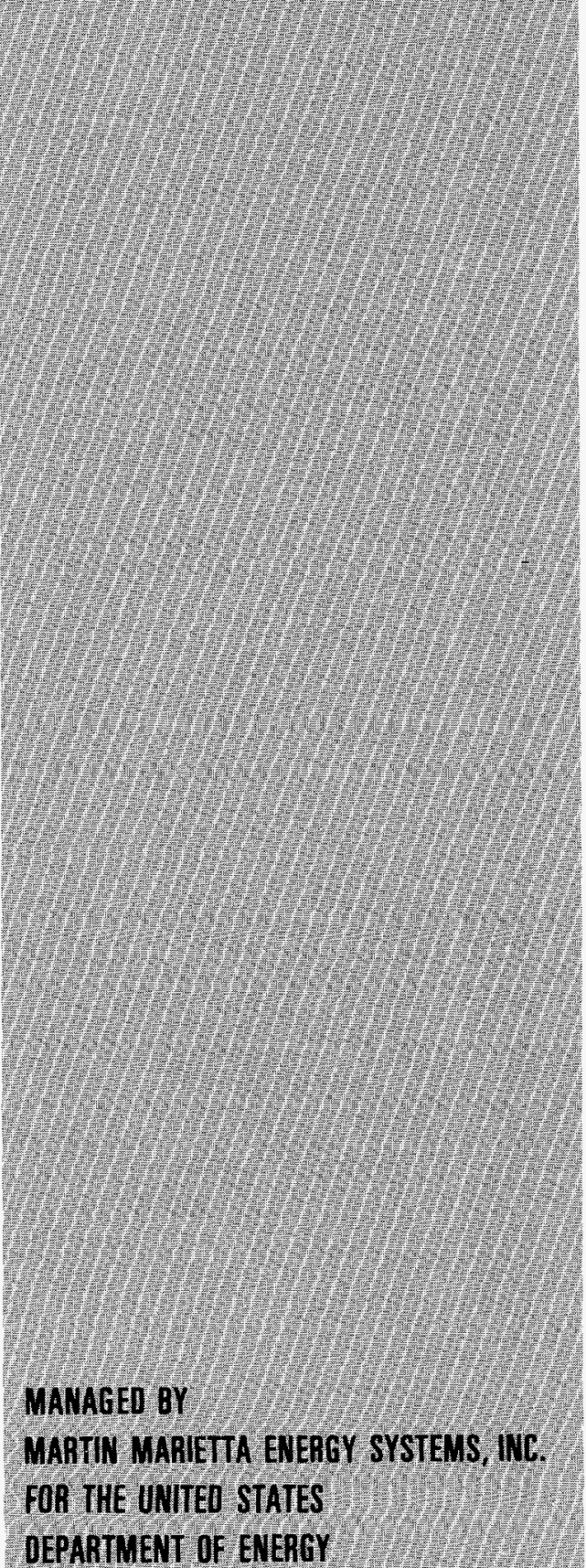

DEPARTMENT OF ENERGY

\section{Groundwater, A Century of Word Evolution}

\author{
A. F. Diefendorf \\ Environmental Sciences Division \\ Publication No. 4446
}


This report has ben reproduced directly from the best available copy.

Available to DOE and DOE contractors from the Office of Scientific and Technical information, P.O. Box 62, Oak Ridge, TN 37831; prices available from (615) 576-8401, FTS 626-8401.

Available to the public from the National Technical Information Service, U.S. Department of Commerce, 5285 Port Royal Rd., Springtield, VA 22161.

This report was prepared as an account of work sponsored by an agency of the United States Government. Neither the United States Government nor any agency thereof, nor any of their employees, makes any warranty. express or implied, or assumes any legal liability or responsibility for the accuracy, completeness, or usefulness of any information, apparatus, product, or process disclosed, or represents that its use would not infringe privately owned rights. Reference herein to any specitic commercial product, process, or service by trade name, trademark, manufacturer, or otherwise, does not necessarily constitute or imply its endorsement, recommendation, or favoring by the United States Government or any agency thereof. The views and opinions of authors expressed herein do not necessarily state or reflect those of the United States Government or any sgency thereot. 


\section{DISCLAIMER}

Portions of this document may be illegible in electronic image products. Images are produced from the best available original document. 
Environmental Sciences Division

\title{
GROUNDWATER, A CENTURY OF WORD EVOLUTION
}

\author{
A. F. Diefendorf \\ Environmental Sciences Division \\ Publication No. 4446
}

Date Published: August 1995

Prepared for

Lockheed Martin Energy Systems, Inc.

Groundwater Program Office

\author{
Prepared by \\ OAK RIDGE NATIONAL LABORATORY \\ Oak Ridge, Tennessee 37831-6035 \\ managed by \\ LOCKHEED MARTIN ENERGY SYSTEMS, INC. \\ for the \\ U.S. DEPARTMENT OF ENERGY \\ under contract DE-AC05-84OR21400
}


0

- 


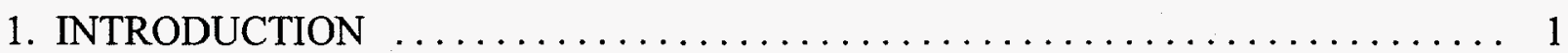

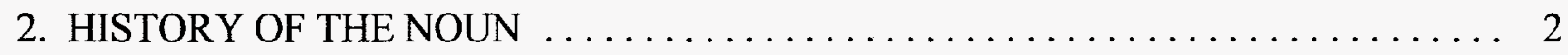

2.1 The Early History -2000 Years of Gestation $\ldots \ldots \ldots \ldots \ldots \ldots \ldots \ldots \ldots \ldots$

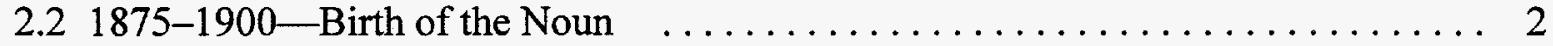

2.3 1900-1925-Limited Use and Mixed Noun Forms ................... 2

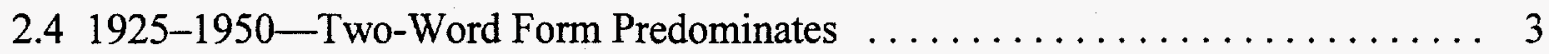

$2.51950-1960-$ Compounding of the Noun Initiated .................. 3

2.6 1960-1970-Compounding to Groundwater Accelerates .............. 4

2.7 1970-1980-Hydrogeologists and Geohydrologists Entrench ............. 4

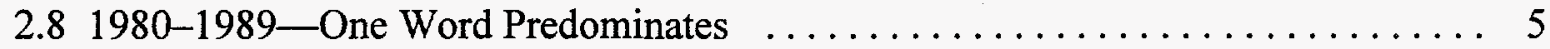

2.9 1990s-The Evolutionary Process Nears Completion $\ldots \ldots \ldots \ldots \ldots \ldots$

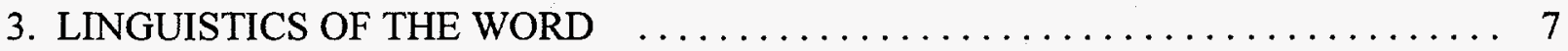

4. USE OF THE COMPOUND ADJECTIVE $\ldots \ldots \ldots \ldots \ldots \ldots \ldots \ldots \ldots \ldots \ldots$

5. CONCLUSIONS AND RECOMMENDATIONS $\ldots \ldots \ldots \ldots \ldots \ldots \ldots$

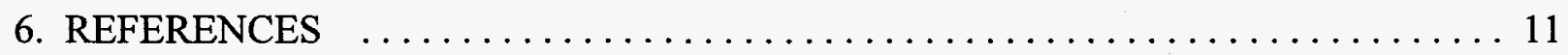


(This Page Left Intentionally Blank) 


\section{INTRODUCTION}

Words, especially those that apply directly to more than one discipline, often become the object of intense debate among professionals in those disciplines. This is particularly true with those people who have to deal with technical jargon on a day-to-day basis and who are concerned that scientific facts get communicated in as clear and concise a manner as possible. Communications regarding environmental restoration projects for the U. S. Department of Energy are no exception. Lockheed Martin Energy Systems, Inc., its subcontractors and other prime contractors often disagree about the spelling and use of compound words. This frequently results in inconsistent spelling between project reports and incorrect spelling of referenced document titles. The following discussion is an attempt to provide an objective, in-depth examination of the evolution of one particular word and recommendations for its proper and consistent use. This discussion is the result of an extensive literature search conducted within the library system at Oak Ridge National Laboratory as well as the personal geologic libraries of the author and colleagues. The author has attempted to cite only those works produced by recognized names in the related disciplines or those works that constitute common references or glossaries.

Often a debate over the use, form or meaning of a word arises between different but related professions, each claiming ownership of the word. As an example, geology's subdiscipline of hydrogeology focuses on the geologic system as it relates to the properties and behavior of ground water. The engineering hydrology discipline of geohydrology, on the other hand, focuses on the hydraulics of groundwater as it relates to earth materials. The two disciplines have a different perspective, yet they agree on the same definition for their medium of interest-which one discipline calls groundwater and the other calls ground water. Which form is correct?

Both the compound word, groundwater, and its simpler root form, ground water, are accepted noun forms with the same meaning. The importance is that the noun, like many others, be recognized as undergoing transition into a compound word. Compounding of words is an evolutionary process generally initiated by writing habits and a "need" to simplify the writing process. Strunk and White (1979) note that "the steady evolution of the language seems to favor union." The frequent use of an old word to support the latest area of technological interest, such as the environment, often forces this union. Fortunately, compounding words is not abhorrent to most technical readers because it often leads to clarity of communication.

As will be discussed herein, the evolution of the word groundwater to its popular acceptance in the one-word form has taken place over a period of about one hundred years. As with any new word, its initial use, regardless of form, was accepted cautiously. Because the word construction can be in three different forms-ground water, ground-water and groundwater-the potential for different preferences for the word form and inconsistencies in word-form use is great. The following discussions summarize the etymology of the word. Section 2 discusses the history of the noun, Section 3 touches on the linguistics of the word, Section 4 discusses the proper use of modifiers, and Section 5 presents conclusions and recommendations regarding the word's use. 


\section{HISTORY OF THE NOUN}

\subsection{THE EARLY HISTORY—2000 YEARS OF GESTATION}

Written discussions about the occurrence and movement of water beneath the surface of the earth go back at least as far as Aristotle's Meteorologica, but naming of these waters is relatively recent. Agricola (1546), a Saxon physician and chemist, referred to the canales in the earth through which the water flowed like blood in an animal's veins. Athanasius Kircher (1678), a Thuringian Jesuit, discussed water-chambers and the juices of minerals. The French and Germans were actively engaged in hydrologic theory in the late 1800 s-including such scientists as Darcy (1856) and Dupuit (1863). During Henri Darcy's time consistent hydrologic terminology began to be used, but at that time in France the waters were referred to as les eaux souterraines. American authors such as Dana (1875) made no reference to groundwater. Even by 1886, Winchell's works either do not mention the subject or refer to underground or subterranean waters.

\subsection{5-1900-BIRTH OF THE NOUN}

The tenth edition of Merriam-Webster's Collegiate Dictionary (1993) gives 1889 as the birth of the word groundwater. The Oxford English Dictionary (1933) gives a date of 1890 and references the journal Nature. These dates of origin correlate well with an English translation of a work by Pošepný (1893) that uses the words ground water and ground-water, both in noun form. Pošepný's original text used typical Germanic compound nouns such as Grundwasser for groundwater and Grundwasserspiegel for groundwater level. The English words for groundwater may be directly derived from the Germanic or as a shortened form of the English underground water. LeConte used the hyphenated word ground-water in his Compend of Geology (1898). So, it appears that the birth of the noun in the English language, regardless of source, was in both the two-word and hyphenated-word form and may also have been in the one-word form.

\subsection{0-1925-LIMITED USE AND MIXED NOUN FORMS}

Publications in the United States that used the word were rare until the beginning of the twentieth century. A review of Mead's (1919) work indicates a persistence in the United States, even during the early 1900 s, to refer to those waters as underground waters, although Mead himself used the two-word form ground water. Most early U. S. Geological Survey (USGS) Professional Papers used underground waters, as did Ambrose as late as 1921. By 1910, however, some articles were using the noun ground water; although, in that same year, G. E. P. Smith published a paper using groundwater in the title. Emmons' (1917) USGS Bulletin on enrichment of ore bodies used the two-word form. The two-word form appears to be the most prevalent in use after the first World War, particularly by such noted hydrologists as Meinzer (1923). 


\subsection{5-1950-THE TWO-WORD FORM PREDOMINATES}

The Oxford English Dictionary (1933), a work of thirteen volumes, had no direct listing for ground water or groundwater. The word ground-water was noted under special constructions of the word ground. The etymology of the two-word form ground water was discussed as "a word or form not found, but of which the existence is inferred." Etymologically, it appears that the noun was used earlier in American English than in British English, even though it was not listed in the Dictionary of American English (1940). Where the word was used in American English publications during this period, the two-word form ground water predominated.

Textbooks on hydrogeology that predate the 1950s are rare; Tolman's (1937) Ground Water being an exception. Treatment of the subject is usually limited to small sections of general geology texts. Troxell (1936) used the hyphenated-word form. Most related information during this period is found in geohydrology textbooks such as Meinzer's (1942) Hydrology. Meinzer generally continued to use the two-word form. Legget (1939) used groundwater in the first edition of his text Geology and Engineering. Some well-known authors of the period, who appear to have been inconsistent in their usage of the noun, included Jacob $(1943,1945)$ and Theis $(1935,1937)$. The well-known geologist M. K. Hubbert (1940) used the two-word form, as did Landes and Wilson (1943). The second edition of Webster's New International Dictionary (1947) appears to be the first listing for the word by Webster's. In this edition the two-word form is presented. Noted soils engineers, Terzaghi and Peck (1948), avoided the use of the noun altogether in their well-known text. Trefethen (1949) in his Geology for Engineers used the two-word form and also frequently used underground water.

\section{$2.51950-1960-$ COMPOUNDING OF THE NOUN INITIATED}

Compounding of word forms generally goes through an intermediate stage wherein the compounded form is usually hyphenated. However, the noun ground-water is rarely found in earlier literature, with the exceptions of LeConte (1898), Troxell (1936) and Peele (1941). Usually the hyphenated form has been reserved for the modifier or adjective form of the noun where the two-word form of the noun is used. Two listings for the noun ground-water were found in 1950s references-one in the Britannica World Language edition of Funk \& Wagnalls New Practical Standard Dictionary (1955) and the other in Dictionary of Geological Terms (Rice 1955). Rice's work used the hyphenated form for both the noun and the adjective.

No British references with the hyphenated form were found for this period. In fact, The Shorter Oxford English Dictionary (1955) had no listing for the noun at all, probably representing general British distaste for additions to their language. However, the apparent establishment of the hyphenated form had taken place and was carried on in Britain in the 1960s, as exhibited in $A$ Dictionary of Geology by John Challinor (1967) and Holmes' (1965) tome on physical geology. 
Rather than use the hyphenated form, most authors of the 1950 s continued to use the two-word form. These authors included Krynine and Judd (1957), Todd (1959) and Walton (1955). The American Geological Institute's first version of its Glossary of Geology (1960) recognized only the two-word noun. It was, however, during this period that the one-word form did become popular with such authors as Ferris and Sayre (1955).

\subsection{0-1970-COMPOUNDING TO GROUNDWATER ACCELERATES}

The evolutionary process of actively compounding ground water into the one-word form appears to have accelerated in the early $1960 \mathrm{~s}$ and was influenced by the activity of geohydrologists as opposed to hydrogeologists. The well-known hydrology text Groundwater and Seepage by Harr (1962) is a good example. The third edition of Webster's New International Dictionary (1961) also combined the words into the one-word form. Most engineering texts, journals and articles have used the compound form since the late 1960s. This includes Walton's (1970) text Groundwater Resource Evaluation. Many others in the forefront of groundwater work used the one-word form during this period, including Cooper (1966), Prickett et al. (1964), Freeze and Witherspoon (1966), and Bredehoeft and Papadopoulos (1965). Many organizations involved with the practical problems of groundwater quickly adopted the one-word form. The American Society of Agricultural Engineers gave the preferred word construction as groundwater in 1967 in its Glossary of Soil and Water Terms, as did Nelson and Nelson (1967) in their Dictionary of Applied Geology.

Vollmer's (1967) Encyclopaedia of Hydraulics, the Bureau of Mines' ( U. S. Department of the Interior 1968) Dictionary of Mining, Mineral and Related Terms, and Elsevier 's Dictionary of Hydrogeology (1969) continued to list the two-word noun with the hyphenated adjective. Noted authors such as DeWiest (1965), Davis and DeWiest (1966), and Legget (1962) preferred the two-word form of the noun. Legget is a rarety in that he split apart the one-word form used in his first edition (1939). Some British factions remained steadfast-no listings were found in The Concise Oxford Dictionary (1964). However, a two-word, unhyphenated form was finally identified in a British reference, the Meteorological Glossary (1963).

\subsection{0-1980-HYDROGEOLOGISTS AND GEOHYDROLOGISTS ENTRENCH}

Open disagreement over the correct use of the word form began in the early 1970s. Few hydrogeologists worked in the private sector at that time; most were employed by the USGS or in academia. Some worked for civil engineering firms and they soon learned that engineers, particularly geohydrologists, had a lot invested in the word groundwater. An engineer once explained to this author that one reason for compounding the word was improved clarity. There was some concern that ground water might actually be interpreted by the layman as water that had been ground up. Later discussions herein somewhat support that concern based on the differences in oral stress between the two different word forms. 
The USGS in its Suggestions to Authors (1978) presented ground water as its preferred form. This, in effect, somewhat polarized many geologists against engineers on the topic. Geologists in the past have been far more insular, academic and resistant to change than those in more publicly active professions. As a result, other professions and the public tend to follow the path set by engineers rather than geologists. This has probably been the single most important element in the rapid evolution and acceptance of the one-word form groundwater. As a result of the apparent influence of those outside the geologic community, as well as others within, the American Geological Institute's 1972 edition of the Glossary of Geology altered from its original version and, instead listed all three word forms. Webster's New Collegiate Dictionary (1973), on the other hand, began to list only the one-word form groundwater. All subsequent Webster's editions, from seventh to tenth, have used that form only. UNESCO's International Glossary of Hydrology (1974) used only the one-word form.

During this period Todd (1980) changed the title of his second edition to Groundwater Hydrology, following in the steps of Walton and others who had already made the conversion. Others, including Domenico (1972), Bredehoeft and Pinder (1973), Neuman (1973), Nuzman (1978) and Bear (1979) used the one-word form in their titles.

Bouwer (1978) used the two-word form in his text, Ground-water Hydrology. Listings of the two-word form found in the 1970s reference literature included Durrenberger's (1973) Dictionary of Environmental Sciences, The American Heritage Dictionary of the English Language (1976), Black's Law Dictionary (1979), the reference text Ground Water and Wells (1972), and the U.S. Department of the Interior's Ground Water Manual (1977). None of those listings had a secondary reference to the one-word form.

\subsection{0-1989-THE ONE-WORD FORM PREDOMINATES}

Some hydrogeologists, geologists and even a few engineers elected to use the two-word convention ground water throughout the 1980s. This continued to undoubtedly be influenced by the USGS and the existence of journals by the National Water Well Association (recently changed to the National Ground Water Association) titled Ground Water and Ground Water Monitoring Review. Of course, changing the name of any well-known and continuously published journal can present some problems.

By the early 1980s the leading college hydrogeology texts were using the one-word form groundwater. Probably the most widely used and referenced hydrogeology text of the 1980 s was Groundwater (Freeze and Cherry 1979). The second most widely used text, Fetter's (1980) Applied Hydrogeology, also used the one-word form. Driscoll (1987) for Johnson Division's second edition of its widely used reference text changed the word form in the text title to Groundwater and Wells. Everett's (1980) major work contributing to the new era of

environmental hydrogeology was titled Groundwater Monitoring. Webster's Third New International Dictionary and Seven Language Dictionary (1986) listed the one-word form only. Webster's II - New Riverside University Dictionary (1984) recognized both the one- and two-word 
forms as did the Random House Dictionary of the English Language (1987). Chamber's Dictionary of Science and Technology (1983) continued to recognize the two-word form only, as did the Environmental Glossary (1984).

The only published discussions that this author was able to locate debating the one-word versus two-word form were in 1986 and 1987 articles published in the journal Ground Water. Ivan Johnson, an engineer, strongly opposed the use of the one-word form in his 1986 article, stating that the form was "definitely two separate words." However, Johnson's documention and citing of sources may have been less than objective or thorough. In his arguement, he notes that a "few older editions" of dictionaries had listed the one-word form and he references only those containing the two-word form. He did not list any of those later references that contained the oneword form only. Some of his one-word references also listed the two-word form; for example: Webster's II New Riverside University Dictionary (1984).

Alan Freeze (1987), coauthor of the highly recognized text Groundwater, responded to Johnson's article in Ground Water with an article titled "Groundwater is Probably One Word (Or Maybe Two), More or Less: An Allegory." This highly tongue-in-cheek allegory points out the extreme nonsensical polarity of the issue using two opposing factions he called "Two worders" and "Oneworders." In the allegory, Freeze's Grand Vizier proclaims via poetry a wise position of compromise-the word form "shall be one-and-a-half!" It is illustrative to note that the journal page containing Freeze's article is immediately preceded by the journal's two-word Ground Water logo, and is ended by a one-quarter page announcement by the Geology Department at Georgia State University for a short course titled Groundwater Geophysics.

\subsection{0 s-THE EVOLUTIONARY PROCESS NEARS COMPLETION}

Apparently, through the 1980s most reference books converted to the one-word form. So, with the exception of a few 1990s holdouts (including the two aforementioned journals both published by the National Ground Water Association), the most widely used noun form has become groundwater. The McGraw-Hill Dictionary of Scientific and Technical Terms (1994) accepts the one-word form only, as does The New Encyclopeedia Britannica (1990) and the Environmental Engineering Dictionary (1992). The Encyclopedia Americana (1993) gives the main listing and description under groundwater and a cross reference only to ground water. The Academic Press Dictionary of Science and Technology (1992) lists groundwater first and ground water as a second version; the two latter references continue to recognize that both word-forms are acceptable, but say that the one-word form is preferred.

The recent growth of concern for the environment has prompted a spate of books on groundwater and remediation including such titles as Groundwater Chemicals Desk Reference (Montgomery and Welkom 1990), Applied Chemical and Isotopic Groundwater Hydrology (Mazor 1991), Applied Groundwater Modeling (Anderson and Woessner 1992), Groundwater Treatment Technology (Nyer 1992), Permeability and Groundwater Contaminant Transport (American Society of Testing and Materials 1979), Migration Processes in the Soil and 
Groundwater Zone (Luckner and Schestakow 1991) and Practical Techniques for Groundwater and Soil Remediation (Nyer 1993). Even law treatises such as Tarlock's (1994) Law of Water Rights and Resources and Want's (1991) Law of Wetlands Regulations defer to the one-word form.

Some continue to use the two-word form almost in defiance of the rest of the scientific and engineering community. Most, however, have agreed that simplicity reduces confusion, and thereby improves communication. Editors for such geological organizations as the American Institute of Professional Geologists now use the one-word form. The Dictionary of the Earth Sciences (Stiegeler 1983) and The Concise Oxford Dictionary of the Earth Sciences (Allaby and Allaby 1990) both use the one-word form groundwater only.

\section{LINGUISTICS OF THE WORD}

The evolution of words into a more compact form also occurs orally. In fact, changes in pronunciation usually occur before changes in spelling. Spelling conventions are usually conservative and less quick to change. According to Gay Marie Logsdon, Ph.D. in English language and linguistics and coordinator of the Editing Office in the Environmental Sciences Division at Oak Ridge National Laboratory, an oral evolution of the word groundwater has already occurred. Her experience suggests that, with few exceptions, most people pronounce groundwater as a compound word with primary stress on the first syllable, or root word, and secondary stress on the second syllable. A comparison of a compound vs two separate words could be made by pronouncing:

\section{greenhouse vs green house}

The compound word is spoken more quickly with primary stress on the syllable green and secondary stress on house; the two-word form is spoken as two distinct words with a slight pause between the words and with equal stress on both words. Similarly the two versions of groundwater can be broken down phonetically:

$$
\begin{array}{ll}
\text { groundwater }=[\text { gráundwàtər }] & \text { (primary stress }+ \text { secondary stress }+ \text { unstress }) \\
\text { ground water }=[\text { gráund wátər }] & \text { (primary stress }+ \text { pause }+ \text { primary stress }+ \text { unstress })
\end{array}
$$

It has been this author's experience that rapid expansion of the public use of certain technical words often accelerates the compounding of those words. People speak the word more frequently, often as an adjective or coupled with other technological words. This seems to result in a slurring or shortening of the pause between the words. For example, in the late 1970s most environmental regulations and dollars expended by the U. S. Environmental Protection Agency (USEPA) were directed at improving facilities for the treatment of municipal waste water. The use of the word waste water became common, particularly in the engineering community, and soon it was compounded into wastewater. 
A more recent example of compounding of water with other words occurred in the same manner. In the early 1990s the USEPA turned its attention toward environmental problems with storm water. Many new regulations directed toward the treatment of storm water were developed. Again. engineers responded to the call. As a result, the noun storm water has almost evolved into stormwater. A recent listing by Lewis Publishers offers ten books on stormwater engineering and two books on storm-water engineering. Compounding of additional words with water has taken place each decade over the past thirty years: wastewater in the 1970s, groundwater in the 1980s and stormwater in the 1990s.

During these evolutionary periods many geologists have sarcastically proposed to the would-be word compounders that a similar logic should be placed on compounding the noun surface water. This suggestion has not been well received. One must be careful in making analogies, because the spelling conventions in the English language are conservative and tied to other arbitrary spelling conventions. For example, this author has observed that the spelled form of a single-syllable word often is more readily combined with a following word than is the spelled form of a two-syllable word. Thus, ground readily combines with water, but surface, as a two-syllable word, does not. Note that the single-syllable words rain, sea, bath and dish have been compounded with water to create the one-word forms rainwater, seawater, bathwater, and dishwater, respectively.

Most of the professional community involved in multidisciplinary work for the public has realized that the simplest word form, regardless of pronunciation, provides the easiest guide for consistency within reports. This need for consistency goes beyond the construction of the noun.

\section{USE OF THE COMPOUND ADJECTIVE}

Use of the one-word form, groundwater, as an adjective eliminates the concern for the meaning of the adjective that might arise from its use in the two-word form. Confusion often arises when it is difficult to differentiate what word or words are being modified by a two-word adjective:

"He went on a wild goose chase." Which was wild, the goose or the chase?

This is usually remedied by hyphenating the two-word form to create a compound adjective:

"He went on a wild-goose chase." The goose was wild; the chase was not.

The U.S. Government Printing Office (1973) and the U.S. Geological Survey (1978) support the use of hyphens as "a valuable tool in clarifying the meaning of multiple modifiers." Both organizations note that use of the hyphen is often a matter of opinion, but they also suggest the following (among many other) hyphenations when two words are "combined to form a unit modifier immediately preceding the term modified." Such as

ground-water study, surface-water study, water-table divide 
With rare exception, most nationally recognized hydrologists and hydrogeologists who have, throughout the century, preferred the use of the two-word form for the noun, ground water, have used ground-water as the companion adjective. The exceptions appear to have been in works produced in the early 1900 s by authors such as Mead (1919) or by others who have limited publications on the subject. Pennink used the hyphenated adjective as early as 1905 . Review of Meinzer's (1942) text indicates that he always used the adjective ground-water, and that the hyphenation process was used in his earlier works (1923). Even soils engineers such as Tschebotarioff (1951) and Peck, Hanson and Thornburn (1953) used the adjective ground-water. The most commonly used hydrogeology text prior to Freeze and Cherry (1979) was Davis and DeWiest's (1966) Hydrogeology. That text, while it used the two-word noun, hyphenated the word each time it was used as an adjective. Van der Leeden (1971) in preparation of his bibliography of ground water hyphenated the adjective. Even Ivan Johnson (1986), who wrote in great opposition to the use of the one-word noun, recognized the appropriate use of the hyphenated modifier, ground-water. Oddly, the Environmental Glossary (1984) used the one-word form as the adjective but the two-word form for the noun..

Nuhfer and Dalles (1989) in their discussions on the correct use of technical terms state

Every science has its own major reference authority for scientific terms and that authority should be used in place of all others as the final authority. Common 'college editions' of dictionaries are neither complete enough nor updated frequently enough to serve the serious technical writer.

They go on to suggest the importance of the American Geological Institute's (1987) Glossary of Geology. All Glossary versions subsequent to the first edition $(1972,1980$, and 1987) have recognized both the one- and two-word forms. All versions suggest hyphenating the two-word form when used as an adjective, the latest edition having 38 listings with ground-water as the modifier.

\section{CONCLUSIONS AND RECOMMENDATIONS}

It is concluded that both the one- and two-word noun versions are correct usages, but the evolutionary trend toward the combined word form, groundwater, currently dominates and is the preferred use by current textbooks in hydrogeology as well as most references and glossaries. Should one desire to use the two-word noun, ground water, then the proper and recommended use of the adjective or modifier is the hyphenated form, ground-water. Use of the one-word noun, groundwater, with its one-word companion adjective, groundwater, eliminates all confusion. Compounding of word forms and condensing them into the simplest possible form is an inevitable process of our language. It does not mean, however, that we have to go overboard with word consolidation, such as the German language where the noun for "field velocity of groundwater" is Grundwasserfliessgeschwindigkeit as noted in Elsevier's Dictionary of Hydrogeology (1969). 
It has been noted that many reports produced by other U. S. Department of Energy contractors and subcontractors are inconsistent in the use of the word forms. Many frequently ignore the appropriate hyphenation of the compound adjective. Some mix different spellings within the same text. Others even change the referenced titles of reports prepared by others by dividing the oneword form into two words. For consistency and clarity, as well as ease of reading and editing, it is suggested that Lockheed Martin Energy Systems, Inc., as the integrating contractor, recommend all internal and external documents regarding U. S. Department of Energy groundwater issues use the preferred one-word form, groundwater, for both the noun and adjective and eliminate any further confusion or discussion on this matter. 


\section{REFERENCES}

Academic Press Dictionary of Science and Technology. 1992. Academic Press, San Diego.

Agricola. 1546. De ortu et causis subterraneorum. pp. 7-11. In H. C. and L. H. Hoover (trs.),

A Source Book in Geology, 1400-1900 (1967). Harvard University Press, Cambridge, Mass.

Allaby, A., and M. Allaby. 1990. The Concise Oxford Dictionary of the Earth Sciences. Oxford University Press, Inc., New York.

Ambrose, A. W. 1921. Use of detectors for tracing movement of underground water. U. S. Bureau Mines Bull. 195.

American Heritage Dictionary of the English Language, The. 1976. Houghton Mifflin Company, Boston.

American Society for Testing and Materials. 1979. Permeability and Groundwater Contaminant Transport. ASTM Special Technical Publication No. 746. Philadelphia.

American Society of Agricultural Engineers. 1967. Glossary of Soil and Water Terms. ASAE Special Publication SP-04-67. St. Joseph, Mich.

Anderson, M. P., and W. W. Woessner. 1992. Applied Groundwater Modeling. Academic Press, Inc., San Diego.

Aristotle. Meteorologica. In E. W. Webster (tr.), The Oxford Translation of the Complete Works of Aristotle, (1923-1955). Vol. 3. Clarendon Press, New York.

Bear, J. 1979. Hydraulics of Groundwater. McGraw-Hill Book Company, New York.

Black's Law Dictionary (5th ed.) 1979. West Publishing Company, St. Paul.

Bouwer, H. 1978. Ground-water Hydrology. McGraw-Hill Book Company, New York.

Bredehoeft, J. D., and I. S. Papadopoulos. 1965. Ratio of vertical groundwater movement estimated from earth's thermal profile. Water Resour. Res. 1:325-328.

Bredehoeft, J. D., and G. F. Pinder. 1973. Mass transport in flowing groundwater. Water Resour. Res. 11:343-347.

Challinor, J. 1967. A Dictionary of Geology. University of Wales Press, Cardiff, Wales.

Chamber's Dictionary of Science and Technology. 1983. W. \& R. Chambers, Edinburgh.

Concise Oxford Dictionary, The. 1964. University Press, Oxford, England.

Cooper, H. H. 1966. The equation of groundwater flow in fixed and deforming coordinates. J. Geophys. Res. 71.

Dana, J .D. 1875. The Geological Story Briefly Told. American Book Company Publishers, Inc., New York.

Darcy, H. 1856. Les fontaines publiques de la Ville de Dijon. Dalmont, Paris.

Davis, S. N., and R. J. M. DeWiest. 1966. Hydrogeology. John Wiley \& Sons, New York.

DeWiest, R. J. M. 1965. Geohydrology. John Wiley \& Sons, New York.

Dictionary of American English. 1940. University of Chicago Press, Chicago.

Domenico, P. A. 1972. Concepts and Models in Groundwater Hydrology. McGraw-Hill Book Company, New York.

Driscoll, F. G. 1987. Groundwater and Wells. Johnson Division Union Oil Products, St. Paul. 
Dupuit, J. 1863. Etudes théoriques et practiques sur le mouvement des eaux dan les canaux découverts et à travers les terrains perméables. Dunod, Paris.

Durrenberger, R. W. 1973. Dictionary of the Environmental Sciences. National Press, Palo Alto, Calif.

Elsevier's Dictionary of Hydrogeology. 1969. H.-O. Pfannkuch (comp.) Elsevier Science Publishing Company, Inc., Amsterdam.

Emmons, W. H. 1917. The enrichment of ore bodies. U.S. Geological Survey Bull. 625.

Encyclopedia Americana - The International Edition. 1993. Vol. 13. Groiler, Inc., Danbury, Conn.

Environmental Glossary. 1984. Government Industries, Rockville, Md.

Environmental Engineering Dictionary (2d ed.). 1992. Government Institutes, Inc., Rockville, Md.

Everett, L. G. 1980. Groundwater Monitoring. General Electric, Schenectady, N.Y.

Ferris, J. G., and A. N. Sayre. 1955. The Quantitative Approach to Groundwater Investigations.

Economic Geology, 50th Anniversary Volume.

Fetter, C. W. 1980. Applied Hydrogeology. Merrill Publishing Company, Columbus, Ohio.

Freeze, R. A. 1987. Groundwater is probably one word (or maybe two), more or less; an allegory. Ground Water. 25(2):219.

Freeze, R. A., and J. A. Cherry. 1979. Groundwater. Prentice Hall, Englewood Cliffs, N.J.

Freeze, R. A., and P. A. Whitherspoon. 1966. A theoretical analysis of regional groundwater

flow. Water Resour. Res. 1(4).

Funk \& Wagnalls New Practical Standard Dictionary of the English Language (Britannica World Language Edition). 1955. Funk \& Wagnalls, New York.

Glossary of Geology. 1960. J. V. Howell (coordinating chairman). American Geological Institute, Washington, D.C.

Glossary of Geology. 1972. M. Gary, R. McAfee, C. L. Wolf (eds.). American Geological Institute, Washington, D.C.

Glossary of Geology. 1980. R. L. Bates and J. A. Jackson (eds.). American Geological Institute., Falls Church, Va.

Glossary of Geology. 1987. R. L. Bates and J. A. Jackson (eds.). American Geological Institute, Alexandria, Va.

Ground Water and Wells. 1972. Johnson Division Union Oil Products, St. Paul.

Hantush, M. S. 1962. Flow of groundwater in sands of nonuniform thickness. J. Geophys. Res. 67.

Hantush, M. S., and C. E. Jacob. 1954. Plane potential flow of ground water with linear leakage.

Trans. Am. Geophys. Union. 35.

Harr, M. E. 1962. Groundwater and Seepage. McGraw-Hill Book Company, New York.

Holmes, A. 1965. Principles of Physical Geology. Ronald Press, New York.

Hubbert, M. K. 1940. The theory of ground-water motion. J. Geol. 48.

Jacob, C. E. 1943. Correlation of ground-water levels and precipitation on Long Island, New

York. Trans. Am. Geophys. Union. 24.

Jacob, C. E. 1945. Correlation of groundwater levels and precipitation on Long Island, New

York. New York Dept. Conserv. Water Power and Control Comm. Bull. GW-14. 
Johnson, A. I. 1986. Ground water is definitely two separate words. Ground Water. 24(5):690-691.

Kircher, A. 1678. Mundus Subterraneus. pp. 17-19. In A Source Book in Geology, 1400-1900. Harvard University Press, Cambridge, Mass.

Kostecki, P. T., and E. J. Calabrese. 1991. Hydrocarbon Contaminated Soils and Groundwater. Lewis Publishers, Chelsea, Mich.

Krynine, D. P., and W. R. Judd. 1957. Principles of Engineering and Geotechnics. McGrawHill Book Company, New York.

Landes, K. K., and J. T. Wilson. 1943. Ground-water exploration by earth-resistivity methods. Papers Mich. Acad. Sci., Let., 29:345-354.

LeConte, J. 1898. Compend of Geology. American Book Co., New York.

Legget, R. F. 1939. Geology and Engineering. McGraw-Hill Book Company, New York.

Legget, R. F. 1962. Geology and Engineering (2d ed.). McGraw-Hill Book Company, New York.

Luckner, L., and W. M. Schestakow. 1991. Migration Processes in the Soil and Groundwater Zone. Lewis Publishers, Chelsea, Mich.

Meteorological Glossary. 1963. Her Majesty's Stationery Office, London.

Mazor, E. 1991. Applied Chemical and Isotopic Groundwater Hydrology. Halstead Press, New York.

McGraw-Hill Dictionary of Scientific and Technical Terms. (5th ed.). 1994. McGraw-Hill Book Company, New York.

McWhorter, D., and D. K. Sunada. 1977. Ground-Water Hydrology and Hydraulics. Water Resources Publications, Littleton, Col.

Mead, D. W. 1919. Hydrology - the Fundamental Basis of Hydraulic Engineering. McGrawHill Book Company, New York.

Meinzer, O. E. 1923. Outline of ground-water hydrology, with definitions. U.S. Geological Survey Water Supply Paper 494.

Meinzer, O. E. 1942. Hydrology. McGraw-Hill Book Company, New York.

Merriam-Webster's Collegiate Dictionary. (10th ed.). 1993. Merriam-Webster, Inc., Springfield, Mass.

Montgomery, J. H., and L. M. Welkom. 1990. Groundwater Chemicals Desk Reference. Lewis Publishers, Chelsea, Mich.

Nelson, A., and K. D. Nelson. 1967. Dictionary of Applied Geology. Philosophical Library Inc., New York.

Neuman, S. P. 1973. Calibration of distributed groundwater flow models viewed as a multipleobjective decision process under uncertainty. Water Resour. Res. 9:1006-1021.

New Encyclopædia Britannica, The. 1990. Encyclopædia Britannica Inc., Chicago.

Nuhfer, E. B., and M. P. Dalles. 1989. Technical Writing as a Process Within a System, with Emphasis on the Earth Sciences. American Institute of Professional Geologists, Denver. Nuzman, C. E. 1978. Groundwater and Well Efficiency. Doerr Metal Products, Larned, Kans. Nyer, E. K. 1992. Groundwater Treatment Technology. (2d ed.). Van Nostrand Reinhold, New York. 
Nyer, E. K. 1993. Practical Techniques for Groundwater and Soil Remediation. Lewis

Publishers, Chelsea, Mich.

Oxford English Dictionary, The. 1933. Clarendon Press, New York.

Peck, R. D., W. E. Hanson and T. H. Thornburn. 1953. Foundation Engineering. John Wiley \& Sons, New York.

Peele, R. 1941. Mining Engineers' Handbook. John Wiley \& Sons, New York.

Pennink, J. M. K. 1905. Investigations for ground-water supplies. Trans. Am. Soc. Civ. Eng., 54(D).

Pošepný, F. 1893. Ground water and the deposition of ore bodies. Trans. Am. Inst. Min. Eng. 33:197-369.

Prickett, T.A., et al. 1964. Groundwater development in several areas of Northeastern Illinois. Illinois State Water Survey Report of Investigation 47.

Random House Dictionary of the English Language (Unabridged, 2d ed.). 1987. Random House, Inc., New York.

Rice, C. W. 1955. Dictionary of Geological Terms. Edwards Bros., Ann Arbor, Mich.

Shorter Oxford English Dictionary, The. 1955. Oxford at the Clarendon Press, Oxford, England. Smith, G. E. P. 1910. Groundwater supply and irrigation in the Rillito Valley. Bull. 64, Agr. Exp. Sta., University of Arizona, Tucson, Ariz.

Stiegeler, S. E. 1983. Dictionary of the Earth Sciences. Rowman and Allanheld, London.

Strunk, W., and E. B. White. 1979. The Elements of Style. (3d ed.). Macmillan Publishing Company, New York.

Tarlock, A. D. 1994. Law of Water Rights and Resources. Clark, Boardman \& Callahan, Deerfield, Ill.

Terzaghi, K., and R. B. Peck. 1948. Soil Mechanics in Engineering Practices. John Wiley and Sons, New York.

Theis, C.V. 1935. The relation between the lowering of the piezometric surface and the rate and duration of discharge of a well using groundwater storage. Trans. Am. Geophys. Union. 16.

Theis, C. V. 1937. Amount of ground-water recharge in the southern high plains. Trans. Am. Geophys. Union. 18.

Todd, D. K. 1959. Ground Water Hydrology. John Wiley \& Sons, New York.

Todd, D. K. 1980. Groundwater Hydrology. John Wiley \& Sons, New York.

Tolman, C. F. 1937. Ground Water. McGraw-Hill Book Company, New York.

Trefethen, J. M. 1949. Geology for Engineers. Van Norstrand, New York.

Troxell, H. C. 1936. The diurnal fluctuation in the ground-water and flow of Santa Ana River and its meaning. Trans. Am. Geophys. Union. 17.

Tschebotarioff, G. P. 1951. Soil Mechanics, Foundations and Earth Structures. McGraw-Hill Book Company, New York.

UNESCO. 1974. International Glossary of Hydrology. UNESCO and World Meteorologic Organization, Geneva.

U.S. Department of the Interior. 1977. Ground Water Manual. U.S. Government Printing Office, Denver. 
U.S. Department of the Interior, Bureau of Mines. 1968. A Dictionary of Mining, Minerals and Related Terms. U. S. Government Printing Office, Washington, D.C.

U.S. Geological Survey. 1978. Suggestions to Authors of the Reports of the United States Geological Survey (6th ed.) U.S. Government Printing Office, Washington, D.C.

U.S. Government Printing Office. 1973. Style Manual. U.S. Government Printing Office, Washington, D.C.

van der Leeden, F. 1971. Ground Water, A Selected Bibliography. Water Information Center, Port Washington, N.Y.

Vollmer, E. 1967. Encyclopaedia of Hydraulics-Soil and Foundation Engineering. Elsevier Science Publishing Company, Inc., Amsterdam.

Walton, W. C. 1955. Ground-water hydraulics as an aid to geologic interpretation. Ohio J. Sci., $55(1)$.

Walton, W. C. 1970. Groundwater Resource Evaluation. McGraw-Hill Book Company, New York.

Want, W. L. 1991. Law of Wetlands Regulations. Clark, Boardman and Callahan, Deerfield, Ill.

Webster's II - New Riverside University Dictionary. 1984. Houghton Mifflin Company, Boston. Webster's New Collegiate Dictionary. 1973. G \& C Merriam, Springfield, Mass.

Webster's Ninth New Collegiate Dictionary. 1984. Merriam-Webster, Inc., Springfield, Mass.

Webster's New International Dictionary (2d ed.,Unabridged). 1947. G \& C Merriam, Springfield, Mass.

Webster's Third New International Dictionary (Unabridged). 1961. G \& C Merriam, Springfield, Mass.

Webster's Third New International Dictionary (Unabridged) and Seven Language Dictionary. 1986. Merriam-Webster, Inc., Chicago.

Winchell, Alexander. 1886. Geological Excursions. S.C. Griggs, Chicago.

Winchell, Alexander. 1886. Walks and Talks in the Geological Field. Chautauqua Press, New York. 
(This Page Left Intentionally Blank) 
INTERNAL DISTRIBUTION

\begin{tabular}{|c|c|}
\hline 1. & F. A. Anderson \\
\hline 2. & L. V. Asplund \\
\hline 3. & L. D. Bates \\
\hline 4. & B. A. Berven \\
\hline 5. & R. B. Clapp \\
\hline 6. & R. B. Cook \\
\hline 7. & J. H. Cushman \\
\hline 8. & V. H. Dale \\
\hline $9-20$. & A. F.Diefendorf \\
\hline 21. & R. B. Dreier \\
\hline 22. & T. O. Early \\
\hline 23. & N. T. Edwards \\
\hline 24. & D. E. Fowler \\
\hline 25. & P. A. Gourieux \\
\hline 26. & C. S. Haase \\
\hline 27. & S. J. Hildebrand \\
\hline 28. & D. D. Huff \\
\hline 29. & G. K. Jacobs \\
\hline 30. & W. K. Jago \\
\hline 31. & P. Kanciriuk \\
\hline 32. & R. H. Ketelle \\
\hline 33. & H. L. King \\
\hline 34. & A. J. Kuhaida \\
\hline 35. & P. J. Lemiszki \\
\hline 36 & J. M. Loar \\
\hline
\end{tabular}

37. G. R. Miller

38. G. R. Moline

39. G. K. Moore

40. C. A. Motley

41. R. S. Poling

42. D. E. Reichle

43. W. L. Richards

44. C. T. Rightmire

45. W. E. Sanford

46. F. E. Sharples

47. D. S. Shriner

48. E. D. Smith

49. S. H. Stow

50. L. E. Toran

51. D. B. Watson

52. S. H. Welch

53. R. K. White

54. S. L. Winters

55. T. F. Zondlo

56. Central Research Library

57-71. ESD Library

72-73. Laboratory Records Dept.

74. Laboratory Records, ORNL-RC

75. ORNL Patent Section

76. ORNL Y-12 Technical Library

\section{EXTERNAL DISTRIBUTION}

77. C. Alvarado, U.S. Department of Energy, Paducah Site Office, P.O. Box 1410, Paducah, KY 42002-1410

78. M. Briodi, Acting Director, Environmental Sciences Division, Department of Energy, 19901 Germantown Road, Germantown, MD 20874

79. D. W. Dollins, U.S. Department of Energy, Paducah Site Office, P.O. Box 1410, Paducah, KY 42002-1410

80. F. A. Donath, Director, Institute for Environmental Education, Geological Society of America, 1006 Las Posas, San Clemente, CA 92673 
81. R. N. Farvolden, Professor, Department of Earth Sciences, University of Waterloo, Waterloo, Ontario N2L 3G1 Canada

82. D. W. Freckman, Director, College of Natural Resources, 101 Natural Resources Building, Colorado State University, Fort Collins, CO 80523

83. A. Patrinos, Director, Environmental Sciences Division, Office of Health and Environmental Research, ER-74, U.S. Department of Energy, Washington, DC 20585

84. M. E. Redfield, U.S. Department of Energy, Paducah Site Office, P.O. Box 1410, Paducah, KY 42002-1410

85. G. S. Sayler, Professor, 10515 Research Drive, Suite 100, The University of Tennessee, Knoxville, TN 37932-2567

86. F. J. Wobber, Environmental Sciences Division, Office of Health and Environmental Research, ER-74, U.S. Department of Energy, Washington, DC 20585

87. Office of Assistant Manager for Energy Research and Development, U.S. Department of Energy Oak Ridge Operations, P.O. Box 2001, Oak Ridge, TN 37831-8600

88-89. Office of Scientific and Technical Information, P.O. Box 62, Oak Ridge, TN 37831 